\title{
Using brand identity to build brand equity: A comparison between the South African and Dutch business-to- business architectural industry
}

\begin{tabular}{|c|c|}
\hline \multicolumn{2}{|c|}{$\begin{array}{l}\text { Authors: } \\
\text { Alet Verster }{ }^{1} \\
\text { Daniël J. Petzer } \\
\text { Nicole Cunningham }\end{array}$} \\
\hline \multicolumn{2}{|c|}{$\begin{array}{l}\text { Affiliations: } \\
{ }^{1} \text { Gordon Institute of Business } \\
\text { Science, University of } \\
\text { Pretoria, Johannesburg, } \\
\text { South Africa }\end{array}$} \\
\hline \multicolumn{2}{|c|}{$\begin{array}{l}{ }^{2} \text { Department of Marketing } \\
\text { Management, University of } \\
\text { Johannesburg, Johannesburg, } \\
\text { South Africa }\end{array}$} \\
\hline \multicolumn{2}{|c|}{$\begin{array}{l}\text { Corresponding author: } \\
\text { Nicole Cunningham, } \\
\text { ncunningham@uj.ac.za }\end{array}$} \\
\hline \multicolumn{2}{|c|}{$\begin{array}{l}\text { Dates: } \\
\text { Received: } 03 \text { Dec. } 2018 \\
\text { Accepted: } 31 \text { Jan. } 2019 \\
\text { Published: } 24 \text { Apr. } 2019\end{array}$} \\
\hline \multicolumn{2}{|c|}{$\begin{array}{l}\text { How to cite this article: } \\
\text { Verster, A., Petzer, D.J. \& } \\
\text { Cunningham, N., 2019, 'Using } \\
\text { brand identity to build brand } \\
\text { equity: A comparison } \\
\text { between the South African } \\
\text { and Dutch business-to- } \\
\text { business architectural } \\
\text { industry', South African } \\
\text { Journal of Business } \\
\text { Management } 50(1), \text { a1372. } \\
\text { https://doi.org/10.4102/ } \\
\text { sajbm.v50i1.1372 }\end{array}$} \\
\hline \multicolumn{2}{|c|}{$\begin{array}{l}\text { Copyright: } \\
\text { (C) 2019. The Authors. } \\
\text { Licensee: AOSIS. This wor } \\
\text { is licensed under the } \\
\text { Creative Commons } \\
\text { Attribution License. }\end{array}$} \\
\hline \multicolumn{2}{|l|}{ Read online: } \\
\hline 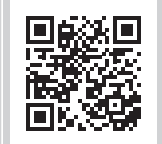 & $\begin{array}{l}\text { Scan this QR } \\
\text { code with your } \\
\text { smart phone or } \\
\text { mobile device } \\
\text { to read online. }\end{array}$ \\
\hline
\end{tabular}

Background: Existing research in the B2B field focuses on relationship marketing and not the importance of building brand equity. By focusing efforts on building brand equity B2B service firms have the opportunity to develop a long-term competitive advantage.

Objective: This study explores how Dutch and South African business-to-business architectural firms compare in their development of brand equity and use of brand identity dimensions. These groups were selected because one (Dutch) holds a favourable brand equity position, while the other (South African) is perceived less favourably. Providing a direct comparison allows the South African business-to-business architectural industry to obtain knowledge and be in a better position to develop their brand equity and identity.

Method: The research was qualitative in nature, where 13 semi-structured interviews were conducted with participants. These respondents were senior partners or marketing specialists in architectural firms in South Africa and the Netherlands.

Results: Differences were observed in the approach to the building blocks of brand equity. South African participants were more focused on internal measures (i.e. personal credibility, previous projects) influencing judgement, while Dutch respondents focused on external measures (i.e. awards, competitions). Dutch individuals developed partnership solutions with their communities, whereas their South African counterparts were reluctant to do so. Differences in the utilisation of brand identity dimensions were also observed among these dimensions: employee and client focus, brand personality, corporate visual identity and consistent communication.

Conclusion: This article provides a direct comparison of brand equity positions showing how those with less favourable brand equity positions can improve their positions.

Keywords: Business-to-business; B2B; brand equity; brand identity; architecture.

\section{Introduction}

Branding assists firms in positioning their products or services in the minds of their customers, thereby differentiating their offerings from those of competitors (Keller, 2013). Business-to-customer (B2C) firms have long understood the benefits of branding, because of the abundance of research available (Coleman, De Chernatony, \& Christodoulides, 2011; Lilien, 2016; Lindgreen, Beverland, \& Farrelly, 2010). However, branding is not restricted to a B2C context, and since the early 2000s researchers have found that business-to-business (B2B) companies can also benefit from using branding to create a competitive advantage (Leek \& Christodoulides, 2012; Lindgreen et al., 2010). Although research in the B2B context has increased, it has focused on how these firms use relationship marketing, with few studies focusing on branding (Glynn, 2012). While relationship marketing remains useful in retaining existing clients, further efforts (such as branding) are required for acquiring new customers (Biedenbach, Bengtsson, \& Wincent, 2011). With most B2B firms focusing on providing a service, clients find it difficult to predict the type of service they will receive because of the intangible nature of services (Glynn, 2012). This leads to the consumers questioning the quality they will get (Mitrache, 2012). Thus, B2B service firms can develop a strong brand identity as an indicator of high-quality services and products (Backhaus, Steiner, \& Lügger, 2011). By starting with developing a strong brand identity, B2B service firms can formulate a positive perception of the brand and in turn create brand equity, leading to a competitive advantage (Coleman et al., 2011).

An industry that needs to use branding to differentiate itself is the South African B2B architectural sector. With the industry becoming more commoditised, clients are less concerned with the 
architectural firm they use to complete a project (Coleman et al., 2011). In turn, this results in low brand equity (Kotler \& Keller, 2016) and decreased profitability (Allix, 2012). The low levels of brand equity reveal that the existing strategies used by South African B2B architectural firms (i.e. relationship marketing) are no longer viable, and a shift in approach needs to occur (Persson, 2010). Thus, to increase the brand equity levels and differentiate themselves, South African B2B architectural firms should focus on developing a strong brand identity (Coleman et al., 2011; Persson, 2010). This has been achieved in the Netherlands, where the architectural industry is renowned for its innovative and high-quality architecture (Kloosterman \& Stegmeiher, 2004), as well as its ability to attract highly qualified and skilled architects (Mirza \& Nacey Research, 2015). This positive perception has led to the Dutch architectural industry holding a favourable brand equity position (Kloosterman \& Stegmeiher, 2004), whereas in the South African architectural industry it is not regarded favourably. This can be attributed to the public's lack of understanding regarding the important role architects play and the lack of marketing and branding efforts by architects themselves (Vosloo, 2015). The aforementioned could be explained by the advertising laws where, prior to the Architectural Act 44 of 2000, architects were not permitted to advertise their services (Mitrache, 2012). Although architects are now allowed to market their services, most have not changed their marketing strategies and still rely heavily on word-of-mouth and relationship marketing (Alecsa \& Popescu, 2015). In instances where these strategies are successful, South African architectural firms discount their fees substantially to secure business from the government (Pather \& Jacobs, 2011). However, this results in price being the predominant selection criteria instead of quality, making it difficult for South African architectural companies to compete sustainably. This causes the industry to become less attractive to both existing and potential architects (Alecsa \& Popescu, 2015). This is clear in the fact that there has been a decrease in the number of registered architectural professionals and the industry being listed on the provisional National Scarce Skills list of the Top 100 Occupations in Demand (Department of Higher Education and Training, 2014; Vosloo, 2015).

However, opportunities for B2B architectural firms in South Africa are abundant, as the growth of the middle class and urbanisation has led to a demand for architectural services, especially from the government, which has committed to increasing infrastructure expenditure over the next decade (National Planning Commission, 2011). Therefore, creating a strong brand will assist in the company's competitive position, leading to greater loyalty and profits (Kotler \& Keller, 2016) and resulting in the architectural firm competing based on quality instead of price (Alecsa \& Popescu, 2015). To achieve this, it would be beneficial for South African architectural businesses to understand the approaches that Dutch architectural firms use to build their brand identity and in turn their brand equity. Consequently, this study aims to explore how South African and Dutch architectural firms compare in their approach to building brand equity and in their use of brand identity to create a favourable position in the industry. By advancing research on B2B branding, this article makes both theoretical and practical contributions. Firstly, there is a large body of research on branding in a B2C context that is not always applicable to B2B service firms. Considering that branding practices may differ in these industries (Leek \& Christodoulides, 2012), this research paper assists in contributing to the limited research on B2B branding, specifically by highlighting how B2B service firms can use brand elements - starting with brand identity - to develop strong brand equity. In addition to contributing to the B2B branding research area, this study also contributes theoretically by drawing comparisons between the architectural industry in two countries: the Netherlands, which holds a favourable brand equity position (Kloosterman \& Stegmeiher, 2004), and South Africa, where the architectural industry is not viewed as favourably (Vosloo, 2015). This comparison will contribute to the understanding of how brand equity and brand identity in a B2B context can be used to develop a favourable position. Practically, this research reveals how B2B service firms should engage in branding efforts to build a stronger position in the market. This is particularly relevant for South Africa, where the architectural industry competes on price and not quality (Alecsa \& Popescu, 2015) and where the demand for B2B architectural services is expected to increase as a result of urbanisation and the growth of the middle class (National Planning Commission, 2011). Furthermore, by providing a direct comparison of the same industry in two different countries where the brand equity positions vary, the South African B2B architectural industry will be in a better position to develop its brand equity and identity.

In the sections that follow, the concept is presented, and an overview of brand equity and identity in a B2B services context is provided. Thereafter, the research methodology and findings are presented, followed by the discussion of the results and the implications thereof.

\section{Conceptual background Brand equity in a business-to-business service context}

Brand equity is defined as the added value endowed on products and services ... reflected in the way consumers think, feel and act with respect to the brand, as well as in the prices, market share and profitability the brand commands'(Kotler \& Keller, 2016). The importance of brand equity has been widely reported in a B2C context, but in a B2B context, relationship marketing has been the focus (Glynn, 2012). However, Biedenbach et al. (2011) report that while relationship marketing strategies are worthwhile for retaining existing clients, the same cannot be said for acquiring new clients or building brand equity. Instead, B2B companies should focus on managing their brand as a whole through building higher levels of brand equity, thus resulting in a long-term competitive advantage (Marquardt, 2013).

Keller's customer-based brand equity (CBBE) model is regarded as the most accurate measure of brand equity (Kuhn, Alpert, \& Pope, 2008). The CBBE is rooted in the 
understanding that the power of a brand in the mind of the client is based on what they have learnt of and experienced with the brand over time. Therefore, marketers should ensure that their clients have a positive experience with the company so that brand equity is developed (Keller, 2013). The CBBE model postulates that building brand equity consists of building blocks, starting with brand identity followed by brand meaning, brand response and resulting in a brand relationship (Keller, 2003). Brand identity forms the basis of the CBBE model and represents the factors clients use to identify the brand; it is also referred to as salience (Pike, 2014). This is where marketers need to ensure that the brand's perceptions are correct before moving on to the next building blocks (Keller, 2013). If this is not addressed correctly, it will have a detrimental effect on the building blocks that follow. Hence, this building block is arguably the most important of the CBBE model (Kuhn et al., 2008). The next level refers to brand meaning, representing what the brand is, based on two building blocks: performance and imagery (Keller, 2003). Performance refers to how well the product or service meets the client's needs (i.e. product features, service effectiveness), while imagery relates to the image the brand portrays in the customer's mind, which can be influenced by their own beliefs or those of the people around them (Altaf, Iqbal, Mokhatar, \& Sial, 2015). This level is followed by two further building blocks: judgement and feelings, which form part of the brand response. A client makes a judgement based on the quality and credibility of the brand, which in turn creates feelings towards the brand (Keller, 2003). The last building block of the CBBE is resonance, which is often referred to as the most difficult yet desirable level to reach as it relates to the relationship that the client has formed with the brand. Reaching this building block is particularly important for service-based firms that thrive on their relationships with clients (Ande, Gunasekaran, Murugesan, \& Natarajan, 2017).

The CBBE model has mostly been applied in a B2C context and authors questioned its applicability to a B2B context (Kuhn et al., 2008; Zaichkowsky, Parlee, \& Hill, 2009). This prompted Kuhn et al. (2008) to apply the CBBE model in a B2B context, with findings revealing that the building blocks of salience, performance and judgement were still relevant in a B2B context, while imagery was replaced with reputation, feelings with sales force relationships and resonance with partnership solutions. Reputation replaced imagery in the $\mathrm{B} 2 \mathrm{~B}$ context, as the reputation of the B2B firm is a strong contributor to the way in which a company perceives another. The replacement of feelings with sales force relationships is important for a B2B context, as employees (i.e. sales force) impact a client's purchasing decision through their communication, technical assistance and knowledge (Kuhn et al., 2008). Lastly, substituting resonance with partnership solutions is justified, as there are different stakeholders involved in a firm, and partnerships should be formed to build successful relationships (Kuhn et al., 2008). For the purpose of this study, understanding brand equity in a B2B context is important. Therefore, the adapted B2B CBBE model developed by Kuhn et al. (2008) was used to obtain an overview of how South African and Dutch B2B architectural firms use the building blocks of brand equity (brand identity, meaning, response and relationships) to develop a favourable position in the market.

While understanding how B2B firms develop brand equity is important, the foundational elements of building brand equity should not be ignored. Brand identity is the foundation of brand equity and subsequently influences the building blocks that follow (Pike, 2014). An overview of brand identity in a B2B context is provided in the next section.

\section{Brand identity in a business-to-business service context}

Brand identity is explained as 'a unique meaning that holds value' (Klopper \& North, 2011), and in a B2B context the focus is on how the brand should be perceived by all stakeholders (Coleman et al., 2011). As mentioned, brand identity is the foundation of the brand equity model in both B2C and B2B, making it a key role player in the creation of brand equity (Keller, 2003). A brand's identity shapes the entire brand strategy and involves creating a unique, valuable meaning (Klopper \& North, 2011) through the internal measures taken by a firm to promote the perception of the brand (Coleman et al., 2011). This is especially important in a B2B context, where brand identity plays an important role in maintaining the client's trust, forming the basis of long-term loyalty and profitable relationships (Burmann, Jost-Benz, \& Riley, 2009). In addition, a B2B services firm with a strong, positive brand identity will inevitably hold a strong and favourable position in the market (Davis, Golicic, \& Marquardt, 2008), leading to the sourcing of new clients (Kumar, Cohen, \& Rajan, 2015). To build a strong and favourable brand identity, Coleman et al. (2011) reported that B2B service firms should ensure the presence and implementation of the five dimensions that manifest in the brand identity concept, known as the B2Bservice brand identity network: human resource initiatives, employee and client focus, consistent communications, corporate visual identity and brand personality. These dimensions are discussed in the next sections.

\section{Human resource initiatives}

In a B2B service firm like an architectural company, employees are the first point of contact for clients, making them the face of the firm (De Chernatony \& Segal-Horn, 2003) and brand representatives (Glynn, 2012). This places importance on the creation of a supportive marketing culture, which can be improved by human resource initiatives like training and performance management (Coleman et al., 2011; Coleman, De Chernatony, \& Christodoulides, 2015), as well as incentives to motivate employee performance (Coleman, 2011). These initiatives lead to more skilled employees who feel satisfied in their role in the firm and remain loyal to it (De Chernatony \& Segal-Horm, 2003; Hutt \& Speh, 2014). This notion is represented in the service-profit chain, which suggests that satisfied employees contribute to satisfied clients and profit (Chi \& Gursoy, 2009). These human resource 
initiatives are important for the development of a brand's identity, as they include the employees of the company who deliver the service. Coleman et al. (2011) suggest that clients make assumptions on the level of service they will receive based on the skills and behaviour of the employee they are dealing with.

\section{Employee and client focus}

This dimension is twofold, focusing on employees and clients (Coleman et al., 2011). The relationship between an employee and a customer is vital to the success of a B2B service firm (Kotler \& Keller, 2016). Particularly, employees assist in differentiating the brand and building the brand's reputation, and so should be involved in brand-building activities as they are considered front-line staff in a service environment (Coleman et al., 2011). Furthermore, firms should ensure a strong client orientation where employees understand that every interaction with a client holds value (Davis et al., 2008) and has the potential to form the brand's identity (Kotler \& Pfoertsch, 2006). In terms of the client-related element of this dimension, B2B service firms should understand that customers' needs are often more complex than those of B2C service firms. Therefore, the B2B service firm should commit to client orientation, in terms of satisfying the needs and wants of consumers and offering the highest level of value (Coleman et al., 2011; Davis et al., 2008; Kotler \& Keller, 2016). This commitment will offer the B2B service firm a strong brand identity and differential advantage (Coleman et al., 2011).

\section{Consistent communication}

Consistent communication, through messages and methods, reveals the value of the brand to its stakeholders (Horan, O'Dwyer, \& Tiernan, 2011). As there is a high number of service encounters in a B2B context, managing regular, consistent communication is vital (De Chernatony \& SegalHorn, 2003). When referring to consistent communication, many firms believe that delivering consistent communication to their external stakeholders (i.e. clients) should be the focus (Coleman et al., 2011), but a lack of consistent communication to internal stakeholders (i.e. employees) could be detrimental for the firm (Li, Guo, Cao, \& Li, 2018). As employees deliver the service, it is important for them to stay abreast of the latest developments in the firm. Hence, consistent communication of the brand strategy should be conveyed within the company, resulting in consistent communication of the brand identity to clients (Leek \& Christodoulides, 2012). However, it should also be considered that a two-way communication strategy is beneficial as it provides stakeholders the opportunity to report back to the firm. This would permit for continued improvement of the business's brand identity (Juntunen, Saraniemi, Halttu, \& Tähtinen, 2010).

\section{Corporate visual identity}

Corporate visual identity refers to the visual cues (i.e. logo, brand name, slogan, uniforms, and design of premises) that make the brand recognisable (Buil, Catalan, \& Martinez, 2016). As a result of the intangibility of services, these visual cues assist clients in evaluating the services and in turn convey the brand's identity as a tool used to distinguish the brand (Coleman et al., 2011). Therefore, service firms should ensure that all visual cues communicate the brand's identity, although a large body of research has focused on the use of a logo to distinguish a brand. In a B2B context, where clients often visit the offices of the firm, it is vital to ensure all visual cues communicate the quality clients should expect (Cian, Krishna, \& Elder, 2014).

\section{Brand personality}

The brand personality refers to the personality the brand has as if it were a living person (Coleman et al., 2011). This personality allows an emotional connection to be formed between the firm and the client (Coleman et al., 2015; De Chernatony \& Segal-Horn, 2003) and offers the company an opportunity to differentiate itself from its competitors while promoting the value of the brand to clients (Herbst \& Merz, 2011). Some authors argue that in a B2B context, a rational decision-making process occurs and there is no room for emotion (Lindgreen et al., 2010). However, more researchers are reporting the involvement of emotion in a B2B purchase, where decision-makers justify their emotional decisions rationally (Hutt \& Speh, 2014). Developing a strong brand personality assists the company in developing a strong brand identity (Colemanet al., 2015) and thus an emotional connection with the client (Lynch \& De Chernatony, 2004).

Against this conceptual background, two research questions (RQs) were proposed:

- RQ1: Do B2B architectural firms in South Africa and the Netherlands differ in their approach to the building blocks of brand equity?

- RQ2: How do B2B architectural firms in South Africa and the Netherlands differ in their utilisation of the dimensions of the B2B service brand identity network to build a favourable brand identity?

\section{Methodology}

The study was qualitative in nature, following an interpretative research paradigm. As limited research exists regarding the brand identity and brand equity of architectural firms (Glynn, 2012; Leek \& Christodoulides, 2012), the qualitative research approach allowed for an in-depth investigation of aspects related to the two research questions formulated for this analysis. The data was collected through semi-structured personal interviews, which provided an in-depth understanding of how architectural firms in South Africa and the Netherlands compare in their approach to the building blocks on brand equity in a B2B context (Kuhn et al., 2008) and how they compare in their utilisation of the B2B service brand identity network (Coleman et al., 2011) to build a favourable brand identity. Furthermore, insights on brand identity and equity were also explored through the flexibility offered by the semi-structured interview format.

The unit of analysis for this research paper included senior partners or marketing specialists (where applicable, 
depending on the size of the architectural firm) in architectural practices in Pretoria and Johannesburg, South Africa, and in Rotterdam in the Netherlands. Firstly, senior partners were deemed appropriate for smaller architectural firms as marketing activities are often undertaken by senior partners, whereas in larger firms the marketing activities are undertaken by the marketing specialists (Reid, 2008). Secondly, the geographic areas were selected as the unit of analysis as they are the major cities where economic activity can be found. Purposive sampling was selected, as it allowed the researcher to filter participants based on the size of the architectural firm, which was limited to no more than 20 employees as a result of the variation of resources in large and smaller architectural firms (Reid, 2008), as well as the high non-response rate of larger firms, and based on whether the architectural firm operated within the B2B market with an institutional, commercial and corporate client base.

A total of 13 interviews were conducted, where saturation was achieved after eight interviews with South African architectural firms (one face-to-face interview and seven via Skype) and five face-to-face interviews with architectural firms in the Netherlands. The interviews were recorded and transcribed, and thereafter themes were identified using Atlas.ti - commonly used software for analysing large sections of text, visual or audio data (Smit, 2002). The process outlined by Kuckartz (2014) was followed, whereby the content of the data was analysed and themes were identified. In order to identify the themes, the coding of the data was driven deductively, based on the definitions of the B2B CBBE model and the scale developed by Kuhn et al. (2008). For instance, for the thematic category of 'partnership solutions', terms like loyalty, attachment, community and engagement were used to condense the data into the theme. These terms were based on the definitions provided by Kuhn et al. (2008).

The aim of qualitative research is to deliver accurate results in a trustworthy and rigorous manner. To achieve this in this study, the four criteria suggested by Guba were used: credibility, transferability, dependability and confirmability (Shenton, 2004). Interviews were recorded and transcribed (credibility), field notes were recorded to allow for reflexivity (credibility), researcher bias was declared (confirmability) and different contexts were compared (i.e. architectural firms in South Africa and the Netherlands) to address transferability and dependability. In addition, when conducting qualitative research a common methodological procedure is coding, whereby the salient notions from a large body of text are captured. Thus, the study ensured methodological analysis processes were employed, which included the assessment of the transcriptions to secure the accuracy of the participants' responses, the development of main thematic categories (supported by extant literature) and the coding of the data according to the thematic categories.

\section{Ethical consideration}

Ethical clearance for this study was provided by the GIBS MBA Ethical Committee chaired by Prof. Gavin Price (Ethical clearance number: 2016-01732).

\section{Findings}

The findings are structured according to the two research questions identified earlier.

\section{Differences in approach to the building blocks of brand equity}

In response to the first research question (Do B2B architectural firms in South Africa and the Netherlands differ in their approach to the building blocks of brand equity?), differences were observed in the approaches to the building blocks particularly judgement and partnership solutions. In terms of the approach to the judgement building block, one South African participant focused on how an employee's personal credibility contributes to the overall judgement of the firm:

'My first strategy was to get people that knew me the best in the industry, knew what I was capable of and punted me where they believed I would be successful.'(Participant 8, Director, South Africa).

Another South African respondent highlighted how previous projects built credibility:

'But it becomes easier if you've done three or four large projects. You don't have to convince people if you can do the work. You can just put the CV in front of them and not seem desperate. The profile sort of speaks for itself.' (Participant 4, Director, South Africa)

In contrast, Dutch participants focused on how awards and competitions build credibility (and ultimately influence judgement):

'We won a competition together with another Rotterdam office ... [in conjunction] with the success, let's say especially after [a famous building] ... we were now asked for on several projects in Holland.' (Participant 1, Owner, Netherlands)

Regarding the approach to the partnership solutions building block, one Dutch architectural firm's attention was more on involvement in academia through lecturing and conducting research, which they linked to their strong presence in the industry:

'A very strong focus on the intellectual world of architecture and we did that because of the fact that we liked it very much, we are a part of the ... scene, European scene of architects ... with a strong cultural position.' (Participant 4, Media Manager, Netherlands).

Another Dutch firm hosted architectural tours and workshops around Rotterdam for 'a group of potential clients or project relations or interesting people, so they can meet each other, of course'. This revealed the added value the company places on partnerships for future projects. The Dutch participants also revealed that by forming partnerships with the communities, they were recognised for their architectural efforts:

\footnotetext{
'All these people who really like to live there, they start this book ... they were so happy with their houses and they were all different and they asked [a] photographer to make nice pictures and now we have this real coffee-table book.' (Participant 4 , Director, Netherlands).
} 
Another Dutch architectural form reported receiving letters of thanks:

'It's for me the biggest compliment that citizens of that place wrote me, just to thank me' (Participant 5, Director, Netherlands).

This shows that Dutch architectural firms focus on partnerships that stem from their involvement in the community as a whole and not only clients. The South African participants differed in their approach to partnership solutions, with one respondent reacting negatively to the concept of forming partnerships:

'Over the years I've learnt that the client is not your friend. They can be your friend at the end of the project, but during the project he's still not your friend, because things can turn very quickly. So I'm not one of those people to go and drink a beer with a client...' (Participant 2, Director, South Africa).

This indicates that the South African architectural firms are reluctant to engage in informal relationships with their customers, which was further explained by another South African participant:

'It's got to do with the reputation and professional service ... from the way we conduct ourselves with the client all the way through to our meetings, site meetings, minutes on email, etc. So that full package is quite important to clients and that's something we've managed to establish.'(Participant 7, Director, South Africa).

\section{Differences in the utilisation of the dimensions in the business-to-business service brand identity network}

In response to the second research question (How do B2B architectural firms in South Africa and the Netherlands differ their utilisation of the dimensions of the B2B service brand identity network to build a favourable brand identity?), differences were observed across all of the dimensions, except for the human resources initiatives dimension. Comparisons drawn on each dimension are presented next.

\section{Employee and client focus}

When comparing the responses, differences were observed in that South African participants focused on employees and culture, while the Dutch respondents focused on clients. One South African participant emphasised how they recognise their employees:

'[What] I'm trying to do now is I'm waiting to start using the Facebook page in a way [that] is making people aware of other people in the office. So doing, I want to do once a week slot on the page, saying meet [this employee] ... I think recognition is a very important thing to anybody, especially in our sort of industry.' (Participant 1, Managing Director, South Africa)

Another South African individual mentioned the importance of culture among employees:

'There's a nice culture of the firm where we all contribute, all enjoy, all get involved in everything ... and we know the staff's strengths that this one is good at this and we point them in the right direction.' (Participant 3, Director, South Africa)
In contrast, the Dutch respondents pay more attention to the clients:

'If you are just an old-fashioned architect who is only dealing with buildings or aesthetics, or is very much still going for its own style, and if the clients want something else you make a big problem ... this is not the way it works any more.' (Participant 1 , Owner, Netherlands)

This suggests that Dutch architects place a heavy emphasis on the consumers' needs. Another Dutch participant agreed with the client focus by stating that:

'Because often an architect - it's better now - but when I studied architecture... it was all about you [the architect]. And now, I see that you are with clients, you have to try listen more. And so, ja, listen first, then ask questions, what the client wants, and then you have to find a link, what you are sharing with the client.' (Participant 5, Director, Netherlands)

This reveals a transformation in the architectural industry, going from being employee-focused to more client-focused in the form of co-creation.

\section{Brand personality}

One Dutch individual commented on the two personalities:

'One is maybe a little bit more informal, the other one is maybe better for a little bit cheap or for party dressing. But if you buy one of these brands, you know what you get. The quality is the same.'(Participant 1, Owner, Netherlands)

This indicates that although there are different personalities within the firm, overall the brand personality indicates quality. Another Dutch participant described the firm's brand personality as 'dynamic and innovative and active. Energetic. And I think everyone is aware and everyone feels this.'(Participant 2, Director, Netherlands). In contrast, a South African respondent mentioned that the way in which the architect dresses represents the brand personality:

'Went to a client wearing my shorts. And it was good shorts, good shoes... and as I... walk into the boardroom, one of the developer's other architects walked out with a suit and tie and everything, and as I walked in the owner of the company said that's the way an architect should dress.' (Participant 1, Managing Director, South Africa)

This indicates that South African firms are perhaps more formal and link their attire to a strong brand personality.

\section{Corporate visual identity}

South African participants mentioned the logos of their brand and linked these to the perceived value of the firm: 'People need to know about the brand, they need to know what they're buying into. They need to know they're buying into quality or good service.' (Participant 2, Director, South Africa). Another South African individual added:

'First on the logo - very important... I spent a lot of time with my logo. It was important to make sure the logo is linked to what 
I envisaged the company to be and that is to be a strong firm. It needed to be a very strong entity in the architectural environment, but an entity that... has infinite possibilities.' (Participant 8 , Director, South Africa)

In contrast, the Dutch respondents focused on the use of all of the physical cues to make the company look professional:

'We make booklets, if it's presentation booklets, or project booklets; we really want to do it nice. Everything goes how it should, should look really nice. The same for websites or publications or this kind of things; if we do photos, we do professional photos by professional photographers. We tend to spend a lot of time and energy on it.' (Participant 1, Owner, Netherlands)

Although the frequency of mentions was low for both South African and Dutch participants, 9 of the 13 participants mentioned the dimension and their responses indicated its importance; thus the frequency could be misleading.

\section{Consistent communication}

Overall, the participants linked consistent communication to the same, clear message to all stakeholders, but they differed in their approach. A South African respondent highlighted the importance of constant communication in this industry:

'It's about the presentation, it's about taking it through the invoice to everything, so it all talks to the same language. Ultimately, it's an architectural firm, so it's about design, so you've got to have that thing going through.' (Participant 1, Managing Director, South Africa).

In contrast, a Dutch participant focused on the quality of the communications:

'In general, I see that if you want to radiate quality, if you want to say "I do nice things, I make nice projects", you need to radiate this in all the things you send out. So, if it's a business card, or a nice presentation, or a booklet, you just want to radiate quality in all aspects of your firm actually.' (Participant 1, Owner, Netherlands).

Both groups of individuals focused on the consistent communication with the client, and no participants referred to consistent communication to employees within the firm.

\section{Human resource initiatives}

Differences in this dimension were not observed. Instead, both groups of participants mentioned the importance of continuous training. One South African respondent said:

'I'm very passionate about growing the people I have in the office and keeping them excited about what they're doing.' (Participant 8, Director, South Africa)

While a Dutch individual stated:

'We also make time to let employees go to meetings and congresses.'(Participant 2, Director, Netherlands).

While it appears that training is a focus in this dimension, the partakers mentioned that incentives were less formal, with a Dutch participant adding:
'There is not a very clear policy about that.' (Participant 4, Media Manager, Netherlands).

A South African contributor also highlighted the informality:

'At least once a month [we'll] have a lunch together and we'll go out and go to Gold Reef City... or have a beer.' (Participant 1, Managing Director, South Africa).

South African firms also seem to mentor employees:

'We've initiated a thing in the office where we give everybody a chance to present a project and make sure they get their presentation skills up, but also making them more relaxed to do it.'(Participant 1, Managing Director, South Africa).

This empowers younger employees who are perhaps not as experienced and uplifts their skills.

The aforementioned discussion relates to the deductive analysis. However, two additional themes, the building as the brand and the personal brand of the protagonist, were identified. The first theme related to the physical representation of the brand, where participants mentioned, 'I think a lot of the work that comes to use or where we get new clients from is because of what we've built' (Participant 6 , Director, South Africa). Although this theme could be related to the corporate visual identity of the firm (i.e. physical cues), no respondents made this link. The second theme is connected to the personality of the architect and their personal brand. One partaker mentioned that:

... [a relative] is an architect as well and we had a discussion about it and he's always found, doesn't matter what you call it, people generally appoint people. Not companies. And so... I ended up choosing [the firm's name], which is [related to my name].' (Participant 1, Managing Director, South Africa).

Another participant mentioned:

'... [the director of the firm] has a really strong personality. He's very present, so he's always part of our brand - in particular "his vision and visibility".' (Participant 2, Director, Netherlands).

This indicated that the personality of the architect linked to the personality of the brand itself.

\section{Discussion}

This section is structured according to the research questions identified earlier.

\section{Differences in approach to the building blocks of brand equity}

The results with respect to the first research question (Do B2B architectural firms in South Africa and the Netherlands differ in their approach to the building blocks of brand equity?) reveal that B2B architectural firms in South Africa and the Netherlands differ in their approach to the judgement and partnership solution building blocks of brand equity - both highly positioned building blocks. 
Keller (2003) relates judgement to brand response, and results reveal that South African firms place significant importance on judgement, linking credibility with this building block. This relationship is supported in a B2B context, where clients judge a firm's capabilities based on internal credibility measures like the employee's personal credibility and the company's previous projects (Kuhn et al., 2008). The results show that the South African B2B architectural firms focus more on internal methods of building credibility. Although focusing on internal aspects of credibility is imperative for a B2B services firm (Backhaus et al., 2011), external indicators of credibility are important (Herbst \& Merz, 2011). This is especially true for B2B services as they are intangible; thus providing external indicators of credibility reduces the uncertainty a client may have and indicates the quality of service the client can expect (Backhaus et al., 2011). The Dutch participants revealed that they focused on external indicators of credibility: awards and competitions, which are suggested by Hutt and Speh (2014) to contribute to differentiating the firm and offering a competitive advantage.

Respondents in the Netherlands stated that they focused on partnership solutions through their involvement in their communities. This is supported by Kotler and Pfoertsch (2006), who state that a brand's reach is beyond its clients and includes other stakeholders (i.e. the community). Furthermore, by focusing on the wider stakeholders, businesses can build their brand image and gain a strategic advantage in the industry (Hutt \& Speh, 2014). The Dutch participants revealed the value in this by indicating that the community had written letters thanking them and had published books of their work. In South Africa, the participants were reluctant to entertain the idea of building a friendly relationship with clients. Although formality often reflects higher quality, forging relationships with stakeholders allows for long-term business success and possible referrals (Yan, Yurchisin, \& Watchravesringkan, 2010).

This research question revealed that both groups of participants emphasised the high-order building blocks of brand equity (judgement and partnership solutions), meaning that the foundation of the B2B CBBE model, brand identity, is not a focus area. Research suggests that B2B firms generally prioritise the higher building blocks first as a way of developing brand equity faster, but avoiding the foundation leads to an overall poor development of brand equity (Pike, 2014). Therefore, the second research question centred on the foundation of brand equity.

\section{Differences in the utilisation of the dimensions in the business-to-business service brand identity network}

The results of the second research question (How do B2B architectural firms in South Africa and the Netherlands differ in their utilisation of the dimensions of the B2B service brand identity network to build a favourable brand identity?) revealed that there were differences in all of the dimensions, except for the human resource initiatives dimension.

The findings show that South African participants recognised the importance of employees. In particular, respondents mentioned employee satisfaction, with an emphasis on the firm's culture. This is owing to the fact that a company's culture influences employees' behaviour in such a way that a strong culture provides shared values and goals. This, in turn, leads to an understanding of the 'correct' way of behaving in the firm and leads to employee satisfaction (Martins \& Coetzee, 2007). Once employees are satisfied, they become more dedicated to satisfying clients' needs, as illustrated by the service-profit chain (Chi \& Gursoy, 2009). The Dutch participants highlighted the evolution of the architectural industry in the Netherlands, where co-creation between the architectural firm and the client takes place, focusing more on clients and their community. This finding supports the idea that customers are becoming more involved in the services (i.e. co-creation) they experience, placing more responsibility on themselves (Payne, Storbacka, \& Frow, 2008). Furthermore, Grönroos and Voima (2012) explain that co-creation leads to an increase in the perceived value that the client is receiving, as they are more involved in the process and thus their own satisfaction. This is supported by Davis et al. (2008) and Backhaus et al. (2011), who argue that a great client focus enhances the brand of the B2B service firm and is what leads to a strong competitive advantage.

Concerning the second dimension, brand personality, Dutch participants linked the company's brand personality to the perceived quality of the firm's services. This is supported by Ramaseshan and Tsao (2007) and Herbst and Merz (2011), who state that when a client has a positive perception of a firm's brand personality, it infers trust and quality and impacts brand equity and the competitive advantage of a firm. Business-to-business service firms should aim for a dynamic brand personality, making the personality more realistic and believable (Coleman et al., 2011). The South African participants only linked the brand personality dimension to the way an architect dresses. In a service context, the clothing an employee wears is part of the physical evidence clients use to assess the quality of service they may or may not receive (Yan et al., 2010). In corporate South Africa, conservative formal attire is still a reflection of highquality service (World Business Culture, 2018). However, Kuhn et al. (2008) report that a brand's personality in a service context is more complicated than the garments employees wear. Thus, a brand's personality should be dynamic and not restricted to clothing.

In the corporate visual identity dimension, differences between participants were observed. South African respondents mentioned the brand logo and linked it to the perceived value of the firm, which is supported by SantosVijande, Del Río-Lanza, Suárez-Álvarez and Díaz-Martín (2013). However, Dutch participants revealed that efforts to 
manage the physical evidence in the service firm were important. This view treats corporate visual identity as a holistic dimension and not only a logo. It allows service firms to connect tangible elements with an intangible service to convey the brand identity clearly (Colemanet al., 2011).

The consistency of communication dimension revealed differences among the participants. The South African individuals focused on the need for constant communication, while the Dutch respondents emphasised the quality of the communication. Hutt and Speh (2014) concur that constant communication is an important contributor to the success of a firm, but Palmer (2014) states that although a firm constantly communicates with its clients, this communication may not be relevant or informative. Instead, Horan et al. (2011) mention that clear, high-quality messages are of utmost importance to service firms, as clients review these messages and associate them with the service to be expected. Therefore, creating high-quality messages lessens the perceived risk of utilising a particular service (Backhaus et al., 2011) and has the potential to lead to a positive brand identity (Horan et al., 2011). Both groups of participants neglected to mention the consistent communication dimension among employees, which may lead to employees' disengagement (Chong, 2007). De Chernatony and Segal-Horn (2003) highlight the importance of consistent communication to all stakeholders, not only clients.

Differences among the human resource initiatives dimension were not observed. Instead, both groups referred to the importance of employees in the firm, emphasised by the mention of mentorship and training programmes. Hutt and Speh (2014) state that companies that invest in training and development provide support and further development for employees, which subsequently results in employee satisfaction and loyalty. Furthermore, De Chernatony and Segal-Horn (2003) state that while training and development are essential, formal human resource initiatives (i.e. formal training programmes) should be in place. Participants in South Africa and the Netherlands both reported a lack of formal human resource initiatives and incentives. Ogedegbe (2014) reports that incentives are imperative to motivating employees, improving productivity and decreasing the possibility of employees leaving the firm.

\section{Implications}

The research questions allowed for theoretical and practical contributions. These are discussed in the subsequent sections.

\section{Theoretical implications}

The study offered a deeper understanding of branding in a B2B services context - an area currently considered to be under-researched (Glynn, 2012). Existing literature does not allow for comparisons to be drawn between B2B service firms that have favourable brand equity positions and those that do not. Instead, extant research focuses on the concept of branding in a B2B services context as a whole, which limits the insights gathered. Therefore, this research paper drew comparisons within the same industry, where one group of participants held a less favourable brand equity position (South African B2B architectural industry) compared to the other group (Dutch B2B architectural industry).

Firstly, comparisons between the ways in which the two groups of participants differed in their approach to the building blocks of brand equity (RQ1) were drawn. The participants with the more favourable brand equity position (Dutch) focused more on external methods to building brand equity: awards, competitions and working with the community; while the participants with a less favourable brand equity position (South Africa) were more preoccupied with internal methods (i.e. personal credibility) and more reluctant to develop partnership solutions. This provides a theoretical contribution, as research in the B2B service context currently focuses on the building blocks of brand equity holistically and does not pinpoint the exact strategies that lead to certain B2B service firms holding more favourable brand equity positions. In addition, the study reveals that B2B service firms focus on the higher levels of the brand equity building blocks, contradicting the work of Kuhn et al. (2008), who found that B2B service firms concentrate on all brand equity building blocks equally. This may be explained by the fact that this study looked specifically at a B2B service.

Secondly, comparisons were made between the two groups in terms of their utilisation of the dimensions of the B2B service brand identity network to build a favourable brand identity (RQ2). Although Coleman et al. (2011) suggest that B2B service firms use all dimensions of the brand identity network, the way in which the dimensions should be used was not provided. This limitation may be because of the Coleman et al. (2011) study being quantitative, thereby limiting the insights drawn. As this research paper was qualitative, it provided the opportunity to delve deeper into the way brand identity is utilised and to draw comparisons between the two groups of participants. The study revealed that the two groups differed in all dimensions (except for human resource initiatives), explaining why the one group's brand identity is less favourable. This direct comparison contributes theoretically to the study of the B2B service brand identity network by identifying the well-managed elements within each dimension. Moreover, the study contributed to the dimensions of the network by identifying two additional dimensions: the building as the brand and the personal brand of the protagonist. These dimensions are applicable in a B2B service context and warrant deeper investigation.

\section{Practical implications}

Through the comparisons drawn, this study makes several practical contributions. Overall, the research revealed how B2B service firms with less favourable brand equity positions can learn from B2B service firms holding stronger brand equity positions.

The comparisons drawn from the way in which the two groups of respondents differed in their approach to the 
building blocks of brand equity (RQ1) provided practical insights. The Dutch participants focused on the highest brand equity building block: partnership solutions. Thus, firms with a lower brand equity position could expand their focus to forming partnerships with their broader communities. In contrast, for the South African participants, partnership solutions were not a priority. In South Africa specifically, urbanisation is becoming a reality and there are different communities in need of architectural services (National Planning Commission, 2011). Therefore, by forming partnerships with government in particular, B2B South African architectural companies can create positive relationships. In addition, B2B service firms should pay attention to their external footprint by building their credibility using competitions and awards, as clients trust companies that have obtained awards from independent bodies (Nowak, Thach, \& Olsen, 2006; Wang \& Tsai, 2014).

Through the comparisons, this study also found that there were differences in the utilisation of the dimensions of the B2B service brand identity network to build a favourable brand identity (RQ2). As mentioned, the two groups differed in their use of all the brand identity dimensions (except for human resource initiatives), providing various practical implications. Specifically, firms holding a less favourable brand equity position should satisfy their clients' needs through co-creation, develop a consistent brand personality and focus on the corporate visual indentifying elements.

In terms of satisfying their clients' needs through co-creation, the findings reveal that Dutch participants understood the value in co-creation. As the architectural industry is collaborative, customers should be given the opportunity to share their views and contribute to the success of the architectural project. In a B2B services context, collaborating with clients reduces risk, decreases costs and improves the project (Fjeldstad, Snow, Miles, \& Lettl, 2011). Moreover, cocreation opportunities increase the likelihood of the firm securing the contract (Bughin, 2014). Business-to-business service firms should develop a consistent brand personality, as this provides a human element to the brand and allows clients to form an emotional connection (Coleman et al., 2015; De Chernatony \& Segal-Horn, 2003). For instance, in a B2B services context, the clientele will expect a certain level of formality, and the person managing that account should adhere. As the findings showed, participants linked brand personality with the way in which architects dress, communicating a non-verbal message to the customer. Focusing on the corporate visual identity dimension should not be limited to the logo of the firm. Although a firm's logo is one of the most valuable cues used to identify a firm (Cian et al., 2014), it is not the only element that makes up the corporate visual identity dimension. Instead, B2B service firms should be concerned with all the visual cues, providing clients with the opportunity to assess the type of service they will receive. In a $\mathrm{B} 2 \mathrm{~B}$ services context, clients often visit the offices of their B2B service provider, making the design of the premises an important visual cue for the client (Coleman et al., 2011). Therefore, it is imperative that B2B service firms manage these visual cues (Klopper \& North, 2011) and ensure that the building they operate from speaks to the skillset of the architects within the company.

\section{Limitations and future research}

Extensive information is available regarding branding in a B2C context, but limited information in a B2B service context limits the scope of the research. This study also focused on brand equity and identity dimensions, thereby excluding any external factors influencing branding, which could be an area of future research. Moreover, while semi-structured interviews allowed the researchers to probe for deeper insights, qualitative research limits the generalisability of the research, as interpretations are often subjective (Saunders \& Lewis, 2016). This could be overcome in future research by conducting an empirical investigation using quantitative analysis. Doing so would allow the results to be statistically verified - in particular, testing whether there are statistically significant differences between the South African and the Dutch B2B architectural firms, as well as their approach to building brand equity and the utilisation of brand identity dimensions. Furthermore, as this study focused on the B2B architectural industry, it limits the applicability to other industries, so further research on another B2B service industry could provide a deeper understanding.

\section{Conclusion}

Business-to-business service firms should aim to build their brand identity and brand equity to differentiate themselves and develop a competitive advantage (Coleman et al.2011). However, there is limited research in the B2B services context (Leek \& Christodoulides, 2012; Lindgreen et al.2010), making it difficult for B2B service firms to develop appropriate branding strategies. Therefore, this study attempted to close this gap by conducting a comparison between two groups from two different countries, where one group held a favourable brand equity position and the other had a weaker brand equity position. This comparison allowed for the explanation of the brand equity positions in the same industry. In order to achieve this, the B2B CBBE model by Kuhn et al. (2008) was utilised to compare the approach to brand equity among the two groups and the B2B service brand identity network, which was used to compare the utilisation of the dimensions of brand equity. The results revealed that differences occur in both the approach to brand equity and the dimensions of brand identity. Business-to-business service firms with weaker brand equity positions could utilise these findings to enhance their branding strategies and improve their brand equity position.

\section{Acknowledgements Competing interests}

The views expressed in this article are the views of the researchers and not an official position of the institutions. 


\section{Author's contributions}

A.V. is a master's student who wrote the original research report. D.J.P. supervised A.V. N.C. converted the research report into a journal article.

\section{References}

Alecsa, I. \& Popescu, F. (2015). Project portfolio - Competitive advantage for design \& construction companies marketing their activities. Review of International Comparative Management, 16(5), 635-653.

Allix, M. (2012). The worst seems to be over for architects. Retrieved from http:// www.bdlive.co.za/companies/2012/08/06/theworstseemstobeoverforarchitects

Ande, R. A., Gunasekaran, A., Murugesan, P. \& Natarajan, T. (2017). Brand resonance score for CBBE model: An application in financial services. Benchmarking: An International Journal, 24(6), 1490-1507. https://doi.org/10.1108/BIJ-07-2015-0073

Altaf, M., Iqbal, N., Mokhtar, S. S. M. \& Sial, M. H. (2015). Managing customer-based brand equity through brand experience in Islamic banking. Journal of Islamic Marketing, 8(2), 218-242. https://doi.org/10.1108/JIMA-07-2015-0048

Backhaus, K., Steiner, M. \& Lügger, K. (2011). To invest, or not to invest, in brands? Drivers of brand relevance in B2B markets. Industrial Marketing Management, 40(7), 1082-1092. https://doi.org/10.1016/j.indmarman.2011.09.002

Biedenbach, G., Bengtsson, M. \& Wincent, J. (2011). Brand equity in the professional service context: Analyzing the impact of employee role behavior and customeremployee rapport. Industrial Marketing Management, 40(7), 1093-1102.https:// doi.org/10.1016/j.indmarman.2011.09.007

Bughin, J. (2014). Three ways companies can make co-creation pay off. Retrieved from https://www.mckinsey.com/industries/customer-packaged-goods/our-insights/ three-ways-companies-can-make-co-creation-pay-off

Buil, I., Catalan, S. \& Martinez, E. (2016). The importance of corporate brand identity in business management: An application to the UK banking sector. BRQ Busines Research Quarterly, 19(2), 3-12. https://doi.org/10.1016/j.brq.2014.11.001

Burmann, C., Jost-Benz, M. \& Riley, N. (2009). Towards an identity-based brand equity model. Journal of Business Research, 62(3), 390-397. https://doi.org/10.1016/ j.jbusres.2008.06.009

Chi, C. G. \& Gursoy, D. (2009). Employee satisfaction, customer satisfaction, and financial performance: An empirical examination. International Journal of Hospitality Management, 28(2), 245-253. https://doi.org/10.1016/j.ijhm.2008. 08.003

Chong, M. (2007). The role of international communication and training in infusing corporate values and delivering brand promise: Singapore Airlines' experience. Corporate Reputation Review, 10(3), 201-212. https://doi.org/10.1057/palgrave. crr.155005

Cian, L., Krishna, A. \& Elder, R. S. (2014). This logo moves me: Dynamic imagery from static images. Journal of Marketing Research, 51(2), 184-197. https://doi. org/10.1509/jmr.13.0023

Coleman, D. A. (2011). Service brand identity: Definition, measurement, dimensionality and influence on brand performance. PhD thesis, University of Birmingham Birmingham.

Coleman, D., De Chernatony, L. \& Christodoulides, G. (2011). B2B service brand identity: Scale development and validation. Industrial Marketing Management, 40(7), 1063-1071. https://doi.org/10.1016/j.indmarman.2011.09.010

Coleman, D. A., De Chernatony, L. \& Christodoulides, G. (2015). B2B service brand performance: An empirical investigation in the UK's B2B IT services sector. European Journal of Marketing, 49(7/8), 1139-1162.https://doi.org/10.1108/EJM-03-20130154

Davis, D. F., Golicic, S. L. \& Marquardt, A. J. (2008). Branding a B2B service: Does a brand differentiate a logistics service provider? Industrial Marketing Management, 37(2), 218-227. https://doi.org/10.1016/j.indmarman.2007.02.003

De Chernatony, L. \& Segal-Horn, S. (2003). The criteria for successful service brands. European Journal of Marketing, 37(7/8), 1095-1118. https://doi.org/10.1108/030 90560310477681

Department of Higher Education and Training. (2014). Call for comments on the national scarce skills list: Top 100 occupations in demand. Retrieved from http://www.inseta. org.za/downloads/Top $\% 20100 \% 20$ scarce $\% 2$ skill\%20occupations $\% 20$ in $\% 20$ south $\% 20$ africa.pdf

Fjeldstad, $\varnothing$. D., Snow, C. C., Miles, R. E. \& Lettl, C. (2012). The architecture of collaboration. Strategic Management Journal, 33(6), 734-750. https://doi.org/ $10.1002 / \mathrm{smj} .1968$

Glynn, M. S. (2012). Primer in B2B brand-building strategies with a reader practicum. Journal of Business Research, 65(5), 666-675. https://doi.org/10.1016/j.jbusres. 2011.03.010G

Grönroos, C. \& Voima, P. (2012). Critical service logic: Making sense of value creation and co-creation. Journal of the Academy of Marketing Science, 41(2), 133-150. https://doi.org/10.1007/s11747-012-0308-3

Herbst, U. \& Merz, M. A. (2011). The industrial brand personality scale: Building strong business-to-business brands. Industrial Marketing Management, 40(7), 1072-1081. https://doi.org/10.1016/j.indmarman.2011.09.003

Horan, G., O’Dwyer, M. \& Tiernan, S. (2011). Exploring management perspectives of branding in service SMEs. Journal of Services Marketing, 25(2), 114-121. https:// doi.org/10.1108/08876041111119831
Hutt, M. D. \& Speh, T.W. (2014). Business marketing management B2B. Hampshire: Cengage Learning.

Juntunen, M., Saraniemi, S., Halttu, M. \& Tähtinen, J. (2010). Corporate brand building in different stages of small business growth. Journal of Brand Management, 18(2), 115-133. https://doi.org/10.1057/bm.2010.34

Keller, K. L. (2003). Strategic brand management: Building, measuring, and managing brand equity. Upper Saddle River, NJ: Prentice Hall.

Keller, K. L. (2013). Strategic brand management: Building, measuring and managing brand equity. Harlow, Essex: Pearson Education.

Kloosterman, R. C. \& Stegmeijer, E. S. (2004). Cultural industries in the Netherlands Path-dependent patterns and institutional contexts: The case of architecture in Rotterdam. Petermanns Geographische Mitteilungen, 148(4), 66-73.

Klopper, H. B. \& North, E. (2011). Brand management. Cape Town: Pearson Education.

Kotler, P. T. \& Keller, K. L. (2016). A framework for marketing management (6th edn.). Harlow: Pearson Education.

Kotler, P. \& Pfoertsch, W. (2006). B2B brand management. Berlin: Springer.

Kuckartz, U. (2014). Qualitative text analysis: A guide to methods, practice and using software. London: Sage.

Kuhn, K. L., Alpert, F. \& Pope, N. K. L. (2008). An application of Keller's brand equity model in a B2B context. Qualitative Marketing Research: An International Journal, 11(1), 40-58. https://doi.org/10.1108/13522750810845540

Kumar, V., Cohen, G. S. \& Rajan, B. (2015). Establishing brand equity among businessto-business referral sources in the emerging markets: The case of specialty medical practice. Industrial Marketing Management, 51, 26-34. https://doi. org/10.1016/j.indmarman.2015.04.018

Leek, S. \& Christodoulides, G. (2012). A framework of brand value in B2B markets: The contributing role of functional and emotional components. Industrial Marketing Management, 41(1), 106-114. https://doi.org/10.1016/j.indmarman.2011.11.009

Li, C., Guo, S., Cao, L. \& Li, J. (2018). Digital enablement and its role in internal branding: A case study of Huanyi travel agency. Industrial Marketing Management, 72, 152-160. https://doi.org/10.1016/j.indmarman.2018.04.010

Lilien, G. L. (2016). The B2B knowledge gap. International Journal of Research in Marketing, 33(3), 543-556.https://doi.org/10.1016/j.ijresmar.2016.01.003

Lindgreen, A., Beverland, M. B. \& Farrelly, F. (2010). From strategy to tactics: Building, implementing, and managing brand equity in business markets. Industria Marketing Management, 39(10), 1223-1225. https://doi.org/10.1016/j.indma rman.2010.02.018

Lynch, J. \& de Chernatony, L. (2004). The power of emotion: Brand communication in business-to-business markets. Journal of Brand Management, 11(5), 403-419. https://doi.org/10.1057/palgrave.bm.2540185

Marquardt, A. J. (2013). Relationship quality as a resource to build industrial brand equity when products are uncertain and future-based Industrial Marketing Management, 42(8),1386-1397. https://doi.org/10.1016/j.indmarman.2013. 07.017

Martins, N. \& Coetzee, M. (2007). Organisational culture, employee satisfaction, perceived leader emotional competency and personality type: An exploratory study in a South African engineering company. SA Journal of Human Resource Management, 5(2), 20-32. https://doi.org/10.4102/sajhrm.v5i2.116

Mirza \& Nacey Research. (2015). The architectural profession in Europe 2014: A sector study. Arundel: Mirza \& Nacey Research.

Mitrache, A. (2012). Branding and marketing - an architect's perspective. Procedia Social and Behavioral Sciences, 62, 932-936. https://doi.org/10.1016/j.sbspro. 2012.09.158

National Planning Commission. (2011). National development plan 2030: Our futureMake it work. Pretoria: Sherino Printers.

Nowak, L., Thach, L. \& Olsen, J. E. (2006). Wowing the millennials: Creating brand equity in the wine industry. Journal of Product \& Brand Management, 15(5), 316-323. https://doi.org/10.1108/10610420610685712

Ogedegbe, R. J. (2014). Achieving organisational objectives through human resource management practices. European Journal of Business and Management, 6(16), $18-22$.

Palmer, A. (2014). Principles of services marketing (7th edn). London: McGraw-Hill.

Pather, G. \& Jacobs, K. (2011). Discounted tenders harm public. Business Report, 21 November, p. 18.

Payne, A. F., Storbacka, K. \& Frow, P. (2008). Managing the co-creation of value Journal of the Academy of Marketing Science, 36(1), 83-96. https://doi. org/10.1007/s11747-007-0070-0

Persson, N. (2010). An exploratory investigation of the elements of B2B brand image and its relationship to price premium. Industrial Marketing Management, 39(8), 1269-1277. https://doi.org/10.1016/j.indmarman.2010.02.024

Pike, S. (2014). Destination brand performance measurement over time. In Woodside, A. G. and Kozak, M. (Eds.). Tourists' perceptions and assessments (Advances in culture, tourism and hospitality research), vol. 8, pp. 111-120, Bingley: Emerald Group Publishing Limited.

Ramaseshan, B. \& Tsao, H. Y. (2007). Moderating effects of the brand concept on the relationship between brand personality and perceived quality. Journal of Brand Management, 14(6), 458-466. https://doi.org/10.1057/palgrave.bm.2550090

Reid, M. (2008). Contemporary marketing in professional services. Journal of Services Marketing, 22(5), 374-384. https://doi.org/10.1108/08876040810889148 
Santos-Vijande, M. L., Del Río-Lanza, A. B., Suárez-Álvarez, L. \& Díaz-Martín, A. M. (2013). The brand management system and service firm competitiveness. Journal of Business Research, 66(2), 148-157. https://doi.org/10.1016/j.jbusres.2012.07.007

Saunders, M. \& Lewis, P. (2016). Doing research in business \& management: An essential guide to planning your project. Essex: Pearson Education.

Shenton, A. K. (2004). Strategies for ensuring trustworthiness in qualitative research projects. Education for Information, 22(2), 63-75. https://doi.org/10.3233/EFI2004-22201

Smit, B. (2001). Atlas.ti for qualitative data analysis. Perspectives in Education, 20(3), $65-76$.

Vosloo, C. (2015). Establishing viable architecture firms. Architecture South Africa: Journal of the South African Institute of Architects, 72(May/June), 34-49.
Wang, Y. H. \& Tsai, C. F. (2014). The relationship between brand image and purchase intention: Evidence from award winning mutual funds. The International Journal of Business and Finance Research, 8(2), 27-40.

World Business Culture. (2018). South African dress code. Retrieved from https://www. worldbusinessculture.com/country-profiles/south-africa/culture/business-dress-style/

Yan, R. N., Yurchisin, J. \& Watchravesringkan, K. (2010). Does formality matter? Effects of employee clothing formality on customers' service quality expectations and store image perceptions. International Journal of Retail \& Distribution Management, 39(5), 346-362. https://doi.org/10.1108/09590551111130775

Zaichkowsky, J. L., Parlee, M. \& Hill, J. (2010). Managing industrial brand equity: Developing tangible benefits for intangible assets. Industrial Marketing Management, 39(5), 776-783. https://doi.org/10.1016/j.indmarman.2010.02.017 